\title{
The Influence of Adjuvant Radiotherapy and Single Nucleotide Polymorphisms on Circulating Immune Response Cell Numbers and Phenotypes of Patients With Breast Cancer
}

\author{
NONGNIT LAYTRAGOON LEWIN ${ }^{1,2}$, THITIYA LUETRAGOON ${ }^{1,3^{*}}$, LEVAR SHAMOUN $^{1^{*}}$, DELMY OLIVA ${ }^{2,4}$, \\ BENGT-ÅKE ANDERSSON ${ }^{1,2}$, STURE LÖFGREN ${ }^{1}$, LARS ERIK RUTQVIST ${ }^{5}$ and FREDDI LEWIN ${ }^{4}$ \\ ${ }^{1}$ Department of Laboratory Medicine, Ryhov Hospital, Jönköping, Sweden; \\ ${ }^{2}$ Department of Clinical and Experimental Medicine, Linköping University, Linköping, Sweden; \\ ${ }^{3}$ Department of Medical Technology, Naresuan University, Phitsanulok, Thailand; \\ ${ }^{4}$ Department of Oncology, Ryhov Hospital, Jönköping, Sweden; \\ ${ }^{5}$ Scientific Affairs Group, Swedish Match AB, Stockholm, Sweden
}

\begin{abstract}
Background/Aim: Adjuvant radiotherapy (RT) damages multiple layers of skin, muscle, blood vessels and blood cells that are included within the RT area. Indirect, bystander systemic effects could also develop in cells not directly hit by radiation. Materials and Methods: Ninetythree female patients recovering from breast cancer surgery and 82 female healthy blood donors were analyzed. For identification of systemic adaptive and innate immune response, rapid and low-cost blood-based biomarkers were assayed. Results: Post-operated breast cancer patients had a decreased number of circulating adaptive immune response cells but increased number of circulating immunosuppressive myeloid subpopulations. RT decreased the number of T-cells and platelets without influencing the number of immunosuppressive myeloid subpopulations. Alterations in the number and phenotypes of T-cell subpopulations were associated with SNPs. Conclusion: The combination of RT and immunotherapy might provide optimal treatment for cancer patients.
\end{abstract}

Adjuvant radiotherapy (RT) is an essential treatment of breast cancer and various other solid tumours after surgery. The anti-neoplastic properties of RT are primarily related to DNA damage and cell death. Direct damage in multiple layers of skin, muscle, blood vessels and blood cells that are

\footnotetext{
*These Authors contributed equally to this work.

Correspondence to: Nongnit Laytragoon Lewin, Ph.D., Department of Laboratory Medicine, Ryhov Hospital, Jönköping, Sweden. Tel: +46102422387, e-mail: nongnit.lewin@rjl.se
}

Key Words: Breast cancer, radiotherapy, blood-based biomarkers. included within the RT area could occur. Indirect, bystander systemic effects could also develop in cells not directly hit by radiation. Direct and indirect RT processes could lead to alterations of host immune response and inflammation (1-4).

Monocytes, neutrophils, natural killer (NK) cells and platelets are innate immune response cells that interact with lymphocytes, the adaptive immune response cells (5). Such interactions could result in either the activation or suppression of host immune response (6). Dysregulated numbers and ratios of circulating monocytes to lymphocytes (MLR), neutrophils to lymphocytes (NLR) or platelet to lymphocytes (PLR) suggests poor survival of cancer patients (7).

$\mathrm{CD} 8^{+}$cells in the T-lymphocyte group could be divided into cells expressing high levels of CD8 (CD8bright) with $\alpha / \beta$ heterodimer receptors and cells expressing low levels of CD8 (CD8dim) with $\alpha / \alpha$ homodimer receptors (8-10). Surface CD8 substantially contributes to $\mathrm{CD} 8^{+}$cell-mediated functions such as cytokine production and cytolytic activity (9). Increased number of $\mathrm{CD}^{\mathrm{dim}}$ cells has been associated with immunosuppressed state (10) and cytotoxic T-lymphocyte (CTL) impairment in patients and healthy individuals (11-13).

Granzyme B (GZB), a cytolytic enzyme and perforin (PRF), a pore-forming protein, are the major mediators of granule-exocytosis activity (14). Variation in GZB expression in $\mathrm{CD} 8^{\mathrm{dim}}$ subpopulations due to single nucleotide polymorphisms (SNPs) has been detected in healthy individuals (15). Over-expression of GZB in $\mathrm{CD}^{+}$ cells is a putative biomarker of impaired immunity in systemic lupus erythematosus patients (16).

Blood flow to normal breast tissue is highly variable between subjects, approximated $22 \pm 13 \mathrm{ml} / \mathrm{min}(17,18)$. With this flow rate, innate and adaptive immune response cells in $1,100 \mathrm{ml}$ to $1,750 \mathrm{ml}$ circulating blood could be influenced directly by adjuvant RT. 
The patient immune response status plays an important role in the outcome of patients with cancer (19). The present study aimed to determine systemic immune status of patients after recovery from surgery for breast cancer and the influence of adjuvant RT. The role of certain SNPs was also investigated. Rapid and low-cost methods analysing circulating biomarkers concerning innate and adaptive immune response were applied.

\section{Materials and Methods}

Patients and controls. Ninety-three female breast cancer patients aged over 18 years and scheduled for adjuvant RT after surgery were invited to participate. If they accepted the invitation, peripheral blood was drawn twice. The first baseline sample was obtained after recovery from surgery and before adjuvant $\mathrm{RT}\left(\mathrm{R}_{0}\right)$. The second follow-up sample was obtained directly, after completion of adjuvant RT $\left(\mathrm{R}_{1}\right)$. Eighty two anonymous female healthy blood donors with no history of cancer or use of any immunomodulation agents were included as controls. One peripheral blood sample was obtained from controls.

Informed consent was obtained from all participants. The study was conducted in accordance with the Declaration of Helsinki and the Ethical Board at Linköping approved this investigation.

Adjuvant RT. Adjuvant RT was delivered at the Department of Oncology, Ryhov hospital Sweden, using Varian True beam machines (Varian Lina $2100 \mathrm{CD}$, Paulo Alto, CA, USA). According to size of the remaining breast after recover from partial mastectomy, two parallel opposing tangential fields was used. They were prescribed to the $95 \%$ isodose according to International Commission on Radiation Units (ICRU), a 3-dimensional treatment planning system (Oncentra masterplan v 4.3, Elekta AB, Stockholm, Sweden). The absorbed dose was $50 \mathrm{~Gy}$ in 25 fractions given as 2 Gy per fraction. This treatment required approximately $2 \mathrm{~min}$ per day, 5 days per week for a total of 5 weeks.

Haematology and flow cytometry analysis. The levels of circulating platelets, total white blood cells (WBCs) and their subpopulations were analysed from whole blood samples using System XE5000 (Sysmex Corporation, Kobe, Japan).

Phenotypes of ex vivo, peripheral WBCs were analyzed using Becton Dickinson FACSCanto II flow cytometer (BD Biosciences, San Jose, CA, USA) within three hours. All monoclonal antibodies were purchased from BD Biosciences. These cells were directly stained for surface marker expression of CD3, CD4, CD8, CD11, CD13, CD14, CD33 and CD56 or intracellularly stained for GZB and PRF expression, according to BD's protocol. Phenotypes and the real numbers of circulating blood lymphocyte, monocyte and neutrophil subpopulations were analyzed after gating according to their location.

SNP analysis. High-molecular weight DNA was extracted from ex vivo peripheral blood samples using QIAGEN Bio Robot M48 with MagAttract DNA Blood M48 kits (Qiagen, Valencia, CA, USA). The quantity and quality of DNA was determined by the Pico-green method using Quant-iT ${ }^{\mathrm{TM}}$ Pico Green ${ }^{\mathrm{TM}}$ dsDNA Assay Kit (ThermoFischer Scientific, MA, USA). The Pico Green fluorescence intensity was determined by Hidex Sense Microplate reader (Hidex Oy, Turku, Finland).
Table I. Characteristics of 93 female breast cancer patients.

\begin{tabular}{lc}
\hline Patients & \\
Age (years), median (range) & $65(41-86)$ \\
\hline Tumour & $\mathrm{n}$ \\
Stage & \\
$\leq \mathrm{T} 1$ & 59 \\
$>\mathrm{T} 1$ & 24 \\
Tis & 10 \\
Lymph node status & \\
N0 & 72 \\
$>$ N0 & 21 \\
Histology & \\
DCIS & 11 \\
Ductal & 63 \\
Lobular & 14 \\
Others & 5 \\
Estrogen receptor positive & 77 \\
Progesteron receptor positive & 67 \\
Her 2 receptor positive & 3 \\
Triple negative & 3 \\
\hline
\end{tabular}

Based on our previous investigation, the following SNPs in GZB rs8192917, PRF rs10999426 and PRF rs3758562 were analyzed (15). These SNP sequences were HapMap-validated with Illumina design ability score according to the manufacturer's protocol (20). The genotyping of SNPs was performed at the SNP \& SEQ Technology Platform, Uppsala University, Sweden (www.genotyping.se).

Statistical analysis. Mann-Whitney $U$-test was used for comparisons of immune response parameters between controls and patients before adjuvant $\mathrm{RT}$, patient $\mathrm{R}_{0}$. To examine the influence of adjuvant radiotherapy, Wilcoxon test was used for comparisons between the patients paired blood sample, before adjuvant RT (Patient $\mathrm{R}_{0}$ ) and after adjuvant $\mathrm{RT}$ (Patient $\mathrm{R}_{1}$ ), respectively. All comparisons were two-sided and $p \leq 0.05$ were considered statistically significant.

\section{Results}

Characteristics of patients and controls. A total of 93 female breast cancer patients were prospectively included after recovering from partial mastectomy. Their median age was 65 years (range $=41-86$ years). They were heterogeneous regarding TNM stage, histology and hormone receptor expression in the tumour (Table I).

Eighty-two female healthy blood donors, median age of 56 years (range $=41-70$ years), were included as controls. The median age of patients was higher than the controls, but this did not reach statistical significance.

The phenotypes and the numbers of circulating innate and adaptive immune response cells in controls and patients. After recovery from removal of their breast cancer mass, the patients had lower number of circulating lymphocytes 
Table II. Circulating innate and adaptive immune response parameters in controls and patients before $\left(R_{0}\right)$ or after $\left(R_{l}\right)$ adjuvant radiotherapy.

\begin{tabular}{|c|c|c|c|c|c|}
\hline & $\begin{array}{l}\text { Controls } \\
\text { Median }\end{array}$ & $\begin{array}{c}\text { Patient } R_{0} \\
\text { Median }\end{array}$ & $\begin{array}{c}\text { Patient } \mathrm{R}_{1} \\
\text { median }\end{array}$ & $\begin{array}{c}p \text {-Value* } \\
\text { Control vs. } \\
\text { Patient } \mathrm{R}_{0}\end{array}$ & $\begin{array}{c}p \text {-Value** } \\
\text { Patient } \\
\text { R0 vs } \mathrm{R}_{1}\end{array}$ \\
\hline \multicolumn{6}{|c|}{ A. Real median number of Platelets, WBCs and its subpopulations } \\
\hline WBC $\left(10^{6} / 1\right)$ & 6510 & 5970 & 5005 & ns & $<0.0001$ \\
\hline Lymphocytes & 1965 & 1650 & 1070 & 0.0014 & $<0.0001$ \\
\hline Monocytes & 530 & 520 & 470 & $\mathrm{~ns}$ & 0.018 \\
\hline Neutrophils & 3425 & 3550 & 3265 & ns & $<0.0001$ \\
\hline Eosinophils & 145 & 120 & 130 & ns & $\mathrm{ns}$ \\
\hline Basophils & 30 & 30 & 25 & ns & 0.001 \\
\hline Platelets $\left(10^{6} / 1\right)$ & 229000 & 247000 & 223000 & ns & $<0.0001$ \\
\hline MLR & 0.28 & 0.31 & 0.45 & 0.0067 & $<0.0001$ \\
\hline NLR & 1.86 & 2.27 & 2.91 & 0.0014 & $<0.0001$ \\
\hline PLR & 126 & 156.30 & 202 & $<0.0001$ & $<0.0001$ \\
\hline \multicolumn{6}{|c|}{ B. Real median number and phenotypes of lymphocytes $\left(10^{6} / 1\right)$} \\
\hline $\mathrm{CD}^{+}$ & 1336 & 1078 & 730 & $<0.0001$ & $<0.0001$ \\
\hline $\mathrm{CD}^{6} 6^{+}$ & 299 & 141 & 71 & $<0.0001$ & $<0.0001$ \\
\hline $\mathrm{CD}^{+}{ }^{+} \mathrm{CD} 56^{+}$ & 66 & 54 & 35 & $\mathrm{~ns}$ & 0.0014 \\
\hline $\mathrm{CD}^{+}+$ & 897 & 719 & 531 & 0.0002 & $<0.0001$ \\
\hline $\mathrm{CD}^{+}+$ & 459 & 460 & 286 & $\mathrm{~ns}$ & $<0.0001$ \\
\hline CD8 bright & 334 & 316 & 175 & ns & $<0.0001$ \\
\hline CD8 $8^{\operatorname{dim}}$ & 140 & 136 & 83 & ns & $<0.0001$ \\
\hline CD4/CD8 Ratio & 1.97 & 1,61 & 1.86 & 0.001 & $<0.0001$ \\
\hline \multicolumn{6}{|c|}{ C. Number and phenotype of myelocytes $\left(10^{6} / 1\right)$} \\
\hline \multicolumn{6}{|c|}{ Monocytes } \\
\hline $\mathrm{CD} 3^{+} \mathrm{CD} 56^{+}$ & 30 & 93 & 83 & $<0.0001$ & ns \\
\hline \multicolumn{6}{|l|}{ Neutrophils } \\
\hline $\mathrm{CD}_{13}{ }^{+} \mathrm{CD} 56^{+}$ & 80 & 404 & 371 & $<0.0001$ & ns \\
\hline
\end{tabular}

MLR: Monocyte/lymphocyte ratio; NLR: neutrophils/lymphocyte ratio; PLR: platelet/lymphocyte ratio; ns: non-significant value. *Mann-Whitney $U$-test; ** Wilcoxon test.

compared to controls $(p=0.0014)$ but similar number of monocytes or neutrophils (Table II). As a consequence, the monocyte to lymphocyte ratio (MLR), neutrophils to lymphocyte ratio (NLR) and platelet to lymphocyte ratio (PLR) were statistically significantly increased in the patients $\mathrm{R}_{0}$ (Table II).

Alterations in the phenotypes of lymphocytes (Figure 1), monocytes and neutrophils (Figure 2) were detected in the patients compared to controls. The number of $\mathrm{CD}^{+}, \mathrm{CD}^{+}$ and $\mathrm{CD}^{2} 6^{+}$cells in lymphocyte population were significantly lower in patients $\mathrm{R}_{0}$ compared to controls (Table II and Figure 1). Number of $\mathrm{CD} 13^{+} \mathrm{CD} 56^{+}$cells in monocyte population or neutrophil population were significantly higher ( $p=0.0001$ ) in patients $\mathrm{R}_{0}$ compared to controls (Table II and Figure 2). Decreased ratio of $\mathrm{CD} 4^{+}$to $\mathrm{CD} 8^{+}$cells $(\mathrm{CD} 4 / \mathrm{CD} 8$ ratio) was also detected in the patients $\mathrm{R}_{0}(p=0.001)$.

Adjuvant RT significantly decreased real numbers of all investigated adaptive and innate immune response subpopulations, except eosinophils (Table II). Despite decreasing real numbers of cells, increased MLR, NLR and
PLR were observed in patients $R_{1}$ compared to $R_{0}$ $(p=0.0001)$. At lymphocytes gate, lowest levels of $\mathrm{CD}^{+}$, $\mathrm{CD} 6^{+}, \mathrm{CD}^{+}, \mathrm{CD}^{+}, \mathrm{CD} 8^{\mathrm{dim}}$ and $\mathrm{CD} 8^{\text {bright }}$ cells were also detected in the patients $R_{1}$ compared to patients $R_{0}$ (Table II). A higher CD4/CD8 ratio was also detected after adjuvant RT $(p \leq 0.0001)$. The adjuvant RT had no influence on circulating numbers of $\mathrm{CD} 13^{+} \mathrm{CD} 56^{+}$expressing cell in monocyte or neutrophil gate.

Number of circulating $\mathrm{CD}^{+}$and $\mathrm{CD} 8^{+}$cells expressing $G Z B$ and PRF in relation to SNPs and adjuvant RT. Lower numbers of GZB and PRF expressing in $\mathrm{CD} 4^{+}$cells were detected in patient $\mathrm{R}_{0}$ compared to controls (Table III). The PRF rs375862 AG+GG sequence correlated to increasing real numbers of $\mathrm{PRF}^{+}$cells in $\mathrm{CD}^{+}$dim population of patients compared to controls $(p=0.046)$.

Adjuvant RT decreased the real numbers of lymphocytes expressing GZB and PRF in $\mathrm{CD} 4^{+}$cells and $\mathrm{CD} 8^{+}$cells. Based on the GZB rs8192917 sequences, the number of GZB expressing $\mathrm{CD} 4^{+}, \mathrm{CD} 8^{\text {bright }}$ and $\mathrm{CD} 8^{\mathrm{dim}}$ cells was lower in 


\section{A. Control}
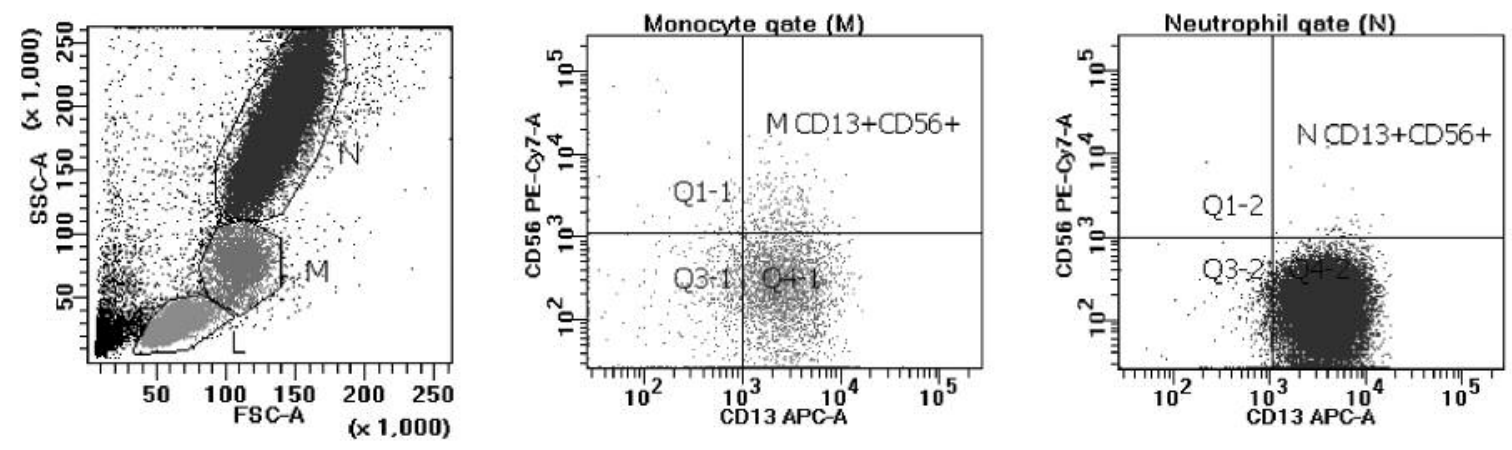

\section{B. Patient $\mathbf{R}_{\mathbf{0}}$}
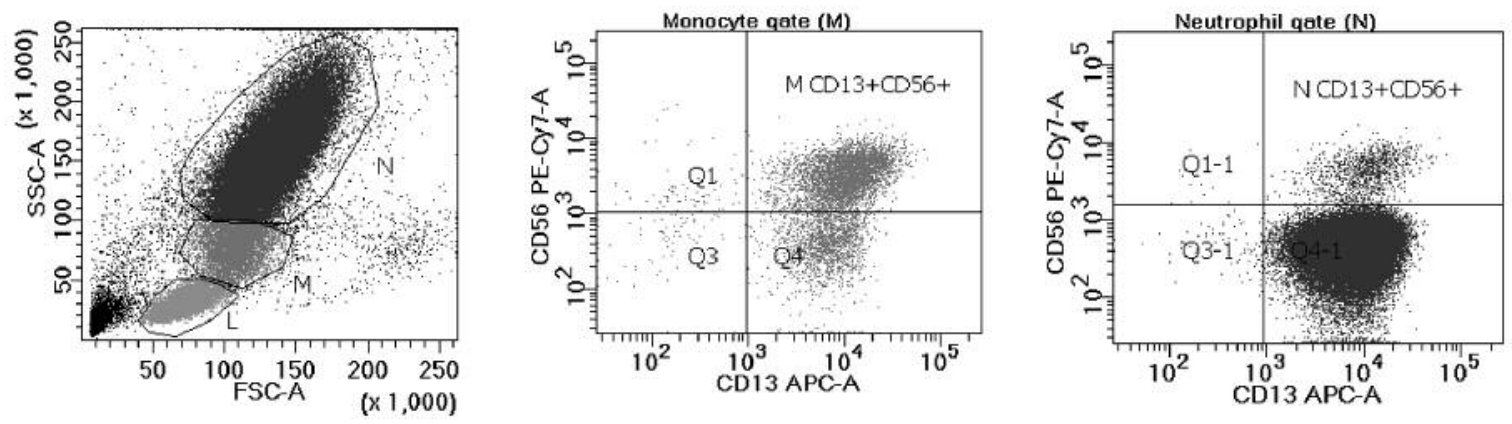

\section{Patient $\mathbf{R}_{1}$}
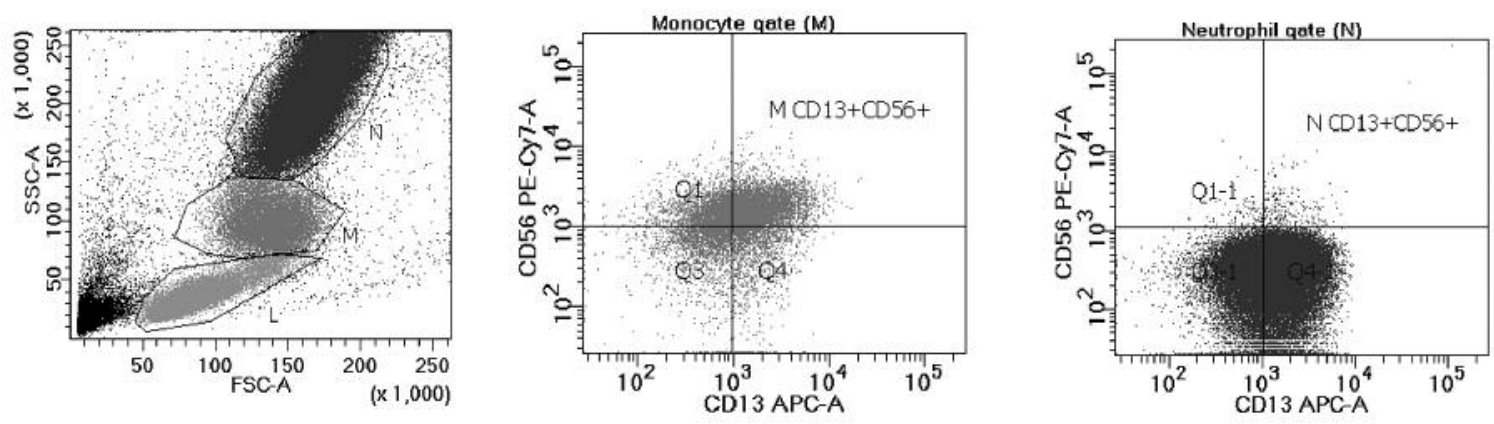

Figure 1. Circulating $C D 13^{+} \mathrm{CD} 56^{+}$cells in monocyte $(M)$ and neutrophil $(N)$ populations. Flow cytometry dot plot results presented ex vivo fresh blood cells of one control (Control) and one breast patient before $\left(R_{0}\right)$ and after $\left(R_{l}\right)$ adjuvant radiotherapy, respectively.

patients $\mathrm{R}_{1}$ than patients $\mathrm{R}_{0}$ (Table III). The influence of adjuvant $\mathrm{RT}$ on PRF expression in $\mathrm{CD} 4^{+}, \mathrm{CD} 8^{\text {bright }}$ and $\mathrm{CD} 8^{\mathrm{dim}}$ differed. Decreased real numbers of $\mathrm{CD} 8^{\mathrm{dim}}$ cells expressing PRF after adjuvant RT were associated with the SNPs in PRF rs 10999426 and PRF rs375862 $(p<0.0001)$ of these patients. The influence of adjuvant RT and SNPs on PRF expression in circulated CD $8^{\text {bright }}$ cells were not detected in these patients.

\section{Discussion}

Real numbers and distribution of innate and adaptive immune response subpopulations play an important role in cancer patients (7). Elevated levels of circulating innate and adaptive immune response cells in patients indicate systemic inflammation and poor survival (7). Decreased numbers of circulating helper T-cells, NK cells and increased number of 


\section{A. Control}
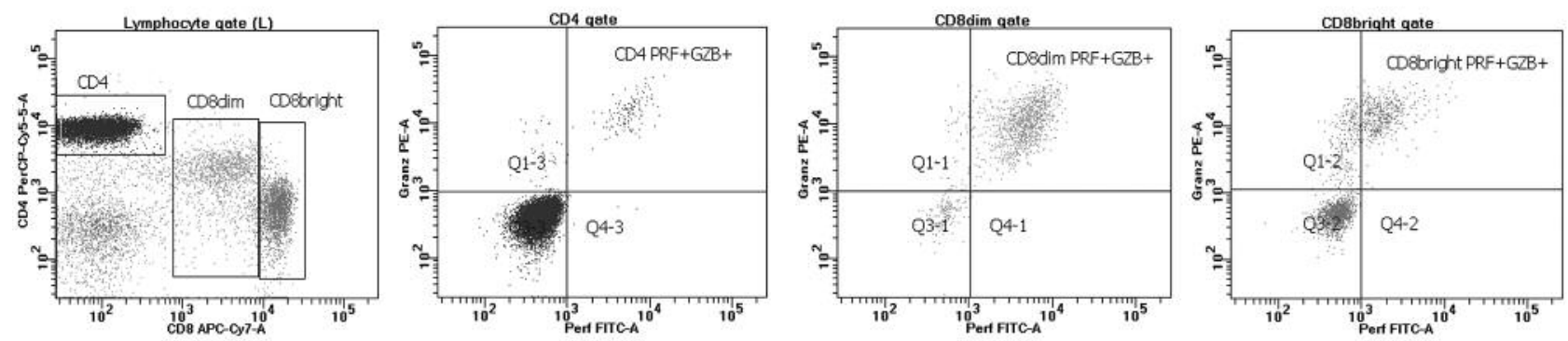

\section{B. Patient $\mathbf{R}_{\mathbf{0}}$}
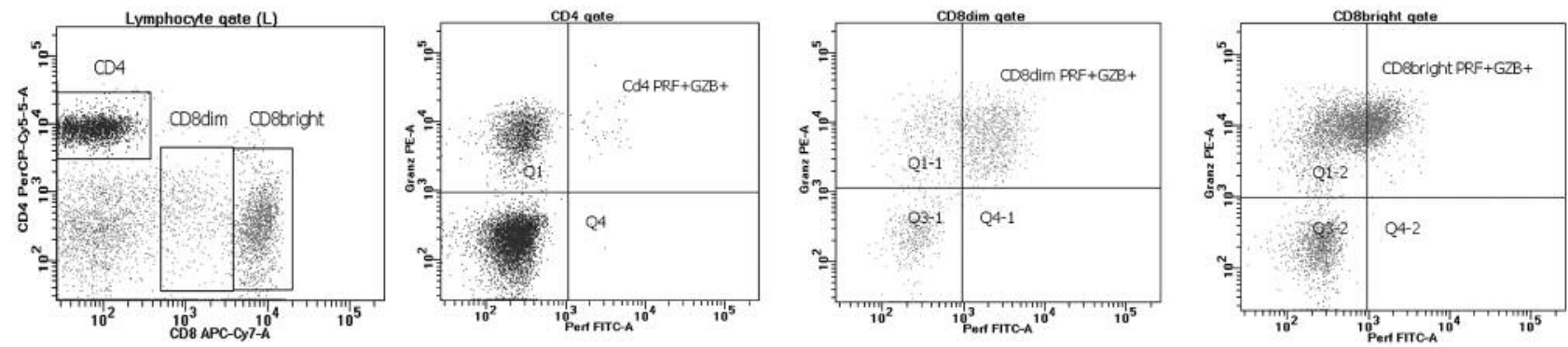

\section{Patient $\mathbf{R}_{1}$}
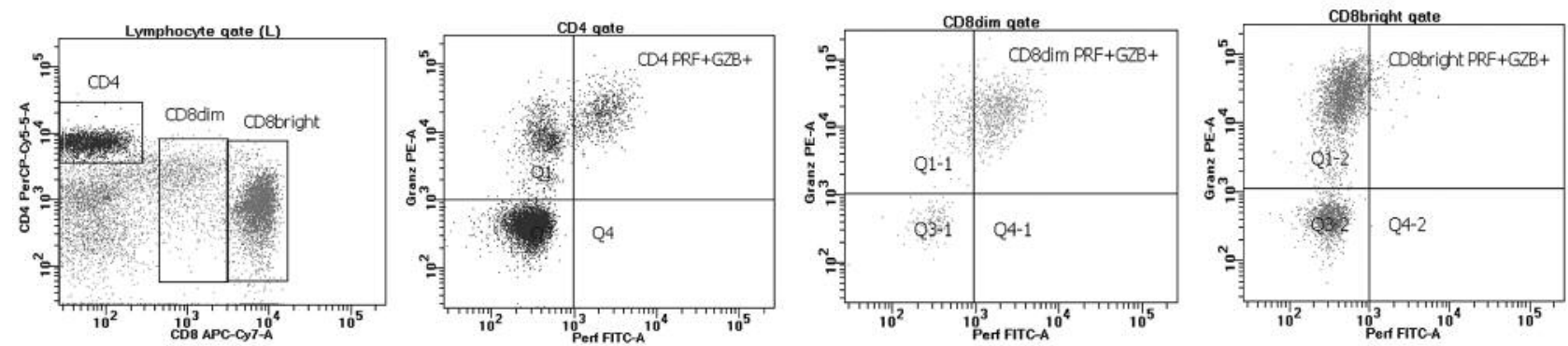

Figure 2. Circulating perforin $\left(P R F^{+}\right)$and granzyme $B\left(G Z B^{+}\right)$expressing $C D 4^{+}, C D 8^{d i m}$ and $C D 8^{\text {bright }}$ cells populations. Flow cytometry dot plot results represented ex vivo fresh blood cells of one control (Control) and one breast cancer patient before (RO) and after (RI) adjuvant radiotherapy, respectively.

immunosuppressive monocytes and neutrophils in cancer patients has been documented $(21,22)$. After the patient's recovery from removal of visible tumour, our investigation suggests that a general immunosuppression persists.

The impact of adjuvant RT on human body is more complex than in in vitro or in vivo models. Blood vessels and blood flow under the treatment area will be affected during adjuvant RT. Given the general blood flow rate, immune response cells in more than $1000 \mathrm{ml}$ blood are expected to be directly in contact with radiation $(17,18)$.

Decreasing platelet numbers in blood circulation after adjuvant RT might be a consequence of platelet activation and consumption due to blood vessel destruction. Adjuvant RT did not influence the real number of circulating $\mathrm{CD} 13^{+} \mathrm{CD} 56^{+}$ monocytes and neutrophils. The impaired immune response in patients $R_{1}$ might associate to decreased numbers of lymphocytes but stable number of immunosuppressive $\mathrm{CD} 13^{+} \mathrm{CD} 56^{+}$monocytes and neutrophils $(21,22)$.

In healthy individuals, the CD4/CD8 ratio declines with age indicating immunological changes due to the ageing process or viral infection $(23,24)$. The decreasing CD4/CD8 ratio is correlated to increased mortality in the elderly (23). Increased circulating $\mathrm{CD} 8^{\mathrm{dim}}$ cells are associated with peripheral exhaustion or impairment of effective CTL $(12,13)$.

SNPs in GZB and PRF genes influence numbers of GZB and PRF expressing cells in blood circulation (15). SNPs in GZB and PRF genes seem to have a higher impact on the numbers of GZB and PFR expressing cells in the CD4 ${ }^{+}$ 
Table III. SNP genotypes and real numbers of circulating granzyme B and perforin expressing cells in controls and patients before $\left(R_{0}\right)$ or after $\left(R_{1}\right)$ adjuvant radiotherapy.

\begin{tabular}{|c|c|c|c|c|c|c|c|c|}
\hline Lymphocyte gate & Gene & rs & Sequence & $\begin{array}{l}\text { Controls (n) } \\
\text { Median } \\
\text { positive cells }\end{array}$ & $\begin{array}{l}\text { Patients } \mathrm{R}_{0}(\mathrm{n}) \\
\text { Median } \\
\text { positive cells }\end{array}$ & $\begin{array}{l}\text { Patients } \mathrm{R}_{1}(\mathrm{n}) \\
\text { Median } \\
\text { positive cells }\end{array}$ & $\begin{array}{c}* \text { Controls } v s . \\
\text { Patients } \mathrm{R}_{0} \\
p \text {-Value }\end{array}$ & $\begin{array}{c}* * \text { Patients } \mathrm{R}_{0} \\
v s . \mathrm{R}_{1} \\
p \text {-Value }\end{array}$ \\
\hline \multirow[t]{2}{*}{$\mathrm{CD} 4^{+}\left(10^{6}\right.$ cells $\left./ 1\right)$} & \multirow[t]{2}{*}{ GZB } & \multirow[t]{2}{*}{8192917} & AA & $90(37)$ & $59(49)$ & $40(45)$ & 0.034 & $<0.0001$ \\
\hline & & & $\mathrm{AG}+\mathrm{GG}$ & $98(12)$ & $39(25)$ & $33(24)$ & ns & 0.013 \\
\hline \multirow[t]{2}{*}{$\mathrm{CD} 8^{\text {bright }}\left(10^{6}\right.$ cells/l $)$} & \multirow[t]{2}{*}{ GZB } & \multirow[t]{2}{*}{8192917} & AA & $125(38)$ & $175(51)$ & $91(45)$ & $\mathrm{ns}$ & $<0.0001$ \\
\hline & & & $\mathrm{AG}+\mathrm{GG}$ & $133(12)$ & $146(27)$ & $60(24)$ & ns & 0.004 \\
\hline \multirow[t]{2}{*}{ CD8 $8^{\operatorname{dim}}\left(10^{6}\right.$ cells/l $)$} & \multirow[t]{2}{*}{ GZB } & \multirow[t]{2}{*}{8192917} & AA & $100(38)$ & $113(50)$ & $54(45)$ & ns & $<0.0001$ \\
\hline & & & $\mathrm{AG}+\mathrm{GG}$ & $90(12)$ & $97(27)$ & $56(24)$ & ns & 0.003 \\
\hline \multirow[t]{2}{*}{$\mathrm{CD}^{+}\left(10^{6}\right.$ cells $\left./ 1\right)$} & \multirow[t]{2}{*}{ PRF } & \multirow[t]{2}{*}{10999426} & $\mathrm{AA}+\mathrm{AG}$ & $27(25)$ & $0(47)$ & $3(45)$ & $<0.0001$ & 0.046 \\
\hline & & & GG & $42(14)$ & $3(28)$ & $6(25)$ & $<0.0001$ & ns \\
\hline \multirow[t]{2}{*}{ CD8 $8^{\text {bright }}\left(10^{6}\right.$ cells $\left./ 1\right)$} & \multirow[t]{2}{*}{ PRF } & \multirow[t]{2}{*}{10999426} & $\mathrm{AA}+\mathrm{AG}$ & $22(31)$ & $21(47)$ & $17(45)$ & ns & ns \\
\hline & & & GG & $26(17)$ & $26(29)$ & $17(25)$ & ns & ns \\
\hline \multirow[t]{2}{*}{$\mathrm{CD} 8^{\mathrm{dim}}\left(10^{6}\right.$ cells/1 $)$} & \multirow[t]{2}{*}{ PRF } & \multirow[t]{2}{*}{10999426} & $\mathrm{AA}+\mathrm{AG}$ & $62(31)$ & $85(47)$ & $36(45)$ & ns & $<0.0001$ \\
\hline & & & GG & $74(18)$ & $82(29)$ & $40(25)$ & ns & $<0.0001$ \\
\hline \multirow[t]{2}{*}{$\mathrm{CD}^{+}\left(10^{6}\right.$ cells/l $)$} & \multirow[t]{2}{*}{ PRF } & \multirow[t]{2}{*}{375862} & $\mathrm{AA}+\mathrm{AG}$ & $37(13)$ & $7(32)$ & $6(28)$ & $<0.0001$ & ns \\
\hline & & & GG & $27(26)$ & $0(44)$ & $1(42)$ & $<0.0001$ & ns \\
\hline \multirow[t]{2}{*}{$\mathrm{CD} 8^{\text {bright }}\left(10^{6}\right.$ cells $\left./ 1\right)$} & \multirow[t]{2}{*}{ PRF } & \multirow[t]{2}{*}{375862} & AA & $33(16)$ & $25(33)$ & $14(28)$ & ns & $\mathrm{ns}$ \\
\hline & & & $\mathrm{AG}+\mathrm{GG}$ & $21(32)$ & $21(44)$ & $17(42)$ & ns & ns \\
\hline \multirow[t]{2}{*}{ CD8 $8^{\operatorname{dim}}\left(10^{6}\right.$ cells $\left./ 1\right)$} & \multirow[t]{2}{*}{ PRF } & \multirow[t]{2}{*}{375862} & AA & $74(17)$ & $81(33)$ & $40(28)$ & ns & $<0.0001$ \\
\hline & & & $\mathrm{AG}+\mathrm{GG}$ & $56(32)$ & $85(44)$ & $37(42)$ & 0.046 & $<0.0001$ \\
\hline
\end{tabular}

GZB: Granzyme B; PRF: perforin; ns: non significant value. *Mann-Whitney $U$-test; **Wilcoxon test.

population than in the CD8+population. Adjuvant RT and GZB rs8192917 influenced the number of circulating GZB expressing $\mathrm{CD}^{+}, \mathrm{CD} 8^{\text {bright }}$ and $\mathrm{CD} 8^{\text {dim }}$ cell populations. The impact of adjuvant RT and SNPs in the PRF gene on the number of cells expressing PRF seem to be pronounced in $\mathrm{CD}^{+}$and $\mathrm{CD} 8 \mathrm{dim}$ cells but not in the $\mathrm{CD} 8^{\text {bright }}$ population. Thus, decreasing numbers of GZB expressing CD $8^{\text {dim }}$ cells, stable numbers of GZB expressing CD $8^{\text {bright }}$ and increasing CD4/CD8 ratio might be the beneficial effects of RT on adaptive immunological functions $(9,25)$.

\section{Conclusion}

A state of immunosuppression persists in breast cancer patients after recovery from removal of visible tumor by surgery. This suppression is manifested by a decreasing number of circulating adaptive immune response, $\mathrm{CD} 4^{+}$cells and increased numbers of immunosuppressive, $\mathrm{CD} 13^{+} \mathrm{CD} 56^{+}$ myeloid cells. Alteration in this adaptive immune response was associated with genotype variations in GZB and PRF genes. Adjuvant RT decreased the real numbers of platelet and adaptive immune response subpopulations without influencing the number of immunosuppressive cells in myelocytes. Our investigation suggests that the combination of RT and immunotherapy may provide an optimized treatment for these patients. The use of these rapid and low-cost blood-based biomarkers for the identification of patient's immune status and the influence of RT needs further investigation.

\section{Conflicts of Interest}

The Authors declare that they have no conflicts of interest to disclose in regard to this study.

\section{Authors' Contributions}

NL, LER, SL and FL designed the studies. TL, LS, DO and B- $\AA A$ included the blood samples and carried out the experiments. All Authors analyzed data, wrote, read and approved the final manuscript.

\section{Acknowledgements}

The Authors would like to thank the patients and healthy blood donors who participated in this study, Tomas Axelsson for SNPs analysis and the staff of Ryhov Hospital, Jönköping for practical support throughout this investigation. Our investigation was supported by the Jönköping Clinical Cancer Research Foundation (Grant 110426-1), Futurum (Grant 144631), FORSS (Grant 567001), the Thai Office of Science and Technology in Brussels, Ministry of Science and Technology. The funders had no influence in the study design, data collection, analysis, preparation or decision to publish this investigation.

\section{References}

1 Okunieff P, Chen Y, Maguire DJ and Huser AK: Molecular markers of radiation-related normal tissue toxicity. Cancer Metastasis Rev 27(3): 363-374, 2008. PMID: 18506399. DOI: $10.1007 / \mathrm{s} 10555-008-9138-7$ 
2 Rodemann HP and Blaese MA: Responses of normal cells to ionizing radiation. Semin Radiat Oncol 17(2): 81-88, 2007. PMID: 17395038. DOI: 10.1016/j.semradonc.2006.11.005

3 Liu H, Li B, Jia X, Ma Y, Gu Y, Zhang P, Wei Q, Cai J, Cui J, Gao F and Yang Y: Radiation-induced decrease of cd8+ dendritic cells contributes to th1/th2 shift. Int Immunopharmacol 46: 178185, 2017. PMID: 28314222. DOI: 10.1016/j.intimp.2017. 03.013

4 Alsbeih G, Al-Harbi N, Al-Hadyan K, El-Sebaie M and Al-Rajhi $\mathrm{N}$ : Association between normal tissue complications after radiotherapy and polymorphic variations in tgfb1 and $\operatorname{xrcc1}$ genes. Radiat Res 173(4): 505-511, 2010. PMID: 20334523. DOI: $10.1667 / R R 1769.1$

5 Murray PJ and Wynn TA: Protective and pathogenic functions of macrophage subsets. Nat Rev Immunol 11(11): 723-737, 2011. PMID: 21997792. DOI: 10.1038/nri3073

6 Mantovani A, Cassatella MA, Costantini C and Jaillon S: Neutrophils in the activation and regulation of innate and adaptive immunity. Nat Rev Immunol 11(8): 519-531, 2011. PMID: 21785456. DOI: $10.1038 /$ nri3024

7 Fox P, Hudson M, Brown C, Lord S, Gebski V, De Souza P and Lee CK: Markers of systemic inflammation predict survival in patients with advanced renal cell cancer. Br J Cancer 109(1): 147-153, 2013. PMID: 23778526. DOI: 10.1038/bjc.2013.300

8 Falanga YT, Frascoli M, Kaymaz Y, Forconi C, Ong'echa JM, Bailey JA, Berg LJ and Moormann AM: High pathogen burden in childhood promotes the development of unconventional innate-like $\mathrm{cd} 8+\mathrm{t}$ cells. JCI Insight 2(15), 2017. PMID: 28768916. DOI: $10.1172 /$ jci.insight.93814

9 Kienzle N, Baz A and Kelso A: Profiling the cd8low phenotype, an alternative career choice for $\mathrm{cd} 8 \mathrm{t}$ cells during primary differentiation. Immunol Cell Biol 82(1): 75-83, 2004. PMID: 14984598. DOI: $10.1111 / \mathrm{j} .1440-1711.2004 .01210 . x$

10 Naji A, Le Rond S, Durrbach A, Krawice-Radanne I, Creput C, Daouya M, Caumartin J, LeMaoult J, Carosella ED and RouasFreiss $\mathrm{N}$ : $\mathrm{Cd} 3+\mathrm{cd} 4$ low and $\mathrm{cd} 3+\mathrm{cd} 8$ low are induced by hla-g: Novel human peripheral blood suppressor t-cell subsets involved in transplant acceptance. Blood 110(12): 3936-3948, 2007. PMID: 17804694. DOI: 10.1182/blood-2007-04-083139

11 Schwaiger S, Wolf AM, Robatscher P, Jenewein B and GrubeckLoebenstein B: Il-4-producing cd8+ $t$ cells with a cd621++(bright) phenotype accumulate in a subgroup of older adults and are associated with the maintenance of intact humoral immunity in old age. J Immunol 170(1): 613-619, 2003. PMID: 12496450. DOI: 10.4049/jimmunol.170.1.613

$12 \mathrm{Xu} \mathrm{H}$, Wang X, Lackner AA and Veazey RS: Cd8 downregulation and functional impairment of siv-specific cytotoxic $t$ lymphocytes in lymphoid and mucosal tissues during siv infection. J Leukoc Biol 93(6): 943-950, 2013. PMID: 23519937. DOI: $10.1189 /$ jlb.1112580

13 Schmitz JE, Forman MA, Lifton MA, Concepcion O, Reimann KA Jr., Crumpacker CS, Daley JF, Gelman RS and Letvin NL: Expression of the cd8alpha beta-heterodimer on $\operatorname{cd} 8(+) \mathrm{t}$ lymphocytes in peripheral blood lymphocytes of human immunodeficiency virus- and human immunodeficiency virus+ individuals. Blood 92(1): 198-206, 1998. PMID: 9639517.

14 Trapani JA, Davis J, Sutton VR and Smyth MJ: Proapoptotic functions of cytotoxic lymphocyte granule constituents in vitro and in vivo. Curr Opin Immunol 12(3): 323-329, 2000. PMID: 10781403 .
15 Luetragoon T, Rutqvist LE, Tangvarasittichai O, Andersson BA, Lofgren S, Usuwanthim K and Lewin NL: Interaction among smoking status, single nucleotide polymorphisms and markers of systemic inflammation in healthy individuals. Immunology 154(1): 98-103, 2018. PMID: 29140561. DOI: 10.1111/imm. 12864

16 Blanco P, Pitard V, Viallard JF, Taupin JL, Pellegrin JL and Moreau JF: Increase in activated $\mathrm{cd} 8+\mathrm{t}$ lymphocytes expressing perforin and granzyme $b$ correlates with disease activity in patients with systemic lupus erythematosus. Arthritis Rheum 52(1): 201-211, 2005. PMID: 15641052. DOI: 10.1002/art.20745

17 Hentschel M, Paulus T, Mix M, Moser E, Nitzsche EU and Brink I: Analysis of blood flow and glucose metabolism in mammary carcinomas and normal breast: A h2(15)o pet and 18ffdg pet study. Nucl Med Commun 28(10): 789-797, 2007. PMID: 17728609. DOI: 10.1097/MNM.0b013e3282e2a880

18 Doughty JC, McCarter DH, Kane E, Reid AW, Cooke TG and McArdle CS: Anatomical basis of intra-arterial chemotherapy for patients with locally advanced breast cancer. Br J Surg 83(8): 11281130, 1996. PMID: 8869324. DOI: 10.1002/bjs.18008 30830

19 Laytragoon-Lewin N, Porwit-MacDonald A, Mellstedt H and Lewin F: Alteration of cellular mediated cytotoxicity, $t$ cell receptor zeta (tcr zeta) and apoptosis related gene expression in nasopharyngeal carcinoma (npc) patients: Possible clinical relevance. Anticancer Res 20(2B): 1093-1100, 2000. PMID: 10810402.

20 Steemers FJ, Chang W, Lee G, Barker DL, Shen R and Gunderson KL: Whole-genome genotyping with the single-base extension assay. Nat Methods 3(1): 31-33, 2006. PMID: 16369550. DOI: $10.1038 /$ nmeth842

21 Serafini P, Borrello I and Bronte V: Myeloid suppressor cells in cancer: Recruitment, phenotype, properties, and mechanisms of immune suppression. Semin Cancer Biol 16(1): 53-65, 2006. PMID: 16168663. DOI: 10.1016/j.semcancer.2005.07.005

22 Muroi K, Fujiwara S, Tatara R, Sugimoto M, Yamamoto C, Uehara E, Meguro A, Hatano K, Okazuka K, Oh I, Ohmine K, Suzuki T, Mori M, Nagai T and Ozawa K: Cd56 expression in normal immature granulocytes after allogeneic hematopoietic stem cell transplantation. J Clin Exp Hematop 53(3): 247-250, 2013. PMID: 24369228.

23 Czesnikiewicz-Guzik M, Lee WW, Cui D, Hiruma Y, Lamar DL, Yang ZZ, Ouslander JG, Weyand CM and Goronzy JJ: T cell subset-specific susceptibility to aging. Clin Immunol 127(1): 107-118, 2008. PMID: 18222733. DOI: 10.1016/j.clim. 2007.12.002

24 Olsson J, Wikby A, Johansson B, Lofgren S, Nilsson BO and Ferguson FG: Age-related change in peripheral blood tlymphocyte subpopulations and cytomegalovirus infection in the very old: The swedish longitudinal octo immune study. Mech Ageing Dev 121(1-3): 187-201, 2000. PMID: 11164473.

25 Jorgensen $\mathrm{PB}$, Livbjerg AH, Hansen HJ, Petersen $\mathrm{T}$ and Hollsberg P: Epstein-barr virus peptide presented by hla-e is predominantly recognized by cd8(bright) cells in multiple sclerosis patients. PLoS One 7(9): e46120, 2012. PMID: 23049954. DOI: 10.1371/journal.pone.0046120

Received July 10, 2019

Revised July 22, 2019

Accepted July 23, 2019 